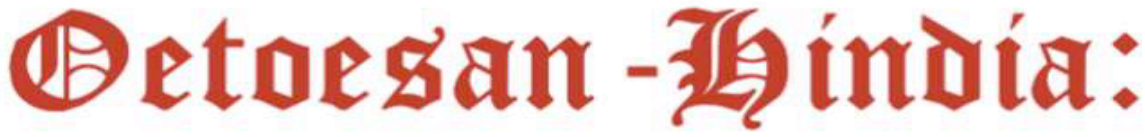

Telaah Pemikiran Kebangsaan

Volume 2 No 2 Tahun 2020 Hlmn. 44-49

Artikel Masuk 10 Agustus 2020 I Artikel Diterima 16 November 2020

\section{Hijrah menuju peradaban yang religius dan berkebangsaan melalui kesadaran pengetahuan dan aksi berketauhidan}

\section{Dzulkarnain Jamil}

Universitas Islam Negeri Sunan Ampel Surabaya, Jl. Ahmad Yani No.117, Jemur Wonosari, Kec. Wonocolo, Kota Surabaya, Jawa Timur 60237

\section{dzulkarnainjamil17@gmail.com}

\begin{abstract}
Abstrak
Tulisan ini mengeksplorasi pemahaman atas Nilai Dasar Kepenelehan serta kesesuaiannya dengan nilai yang diyakini penulis serta kaitannya dengan harapan penulis mengenai peran pemuda dalam peradaban. Yayasan Peneleh Jang Oetama berupaya menyatukan pandangan seluruh Aktivis Peneleh melalui aturan yang berbasis pada pemikiran HOS Cokroaminoto yang berlandaskan Al-qur'an dan alHadits. Terciptalah Insan Kamil yang menyadari bahwa dirinya adalah Abdillah atau hamba Allah. Perlawanan atas paradigma barat yang bersandar para nilai materialisme historis dilakukan dengan melawan kesempitan dan kedangkalan pola pikir Barat tentang manusia dan kehidupan. Upaya perlawanan ini memicu kemerdekaan dan kemandirian dalam berpikir dan bertindak untuk menjadi penggerak hijrah peradaban.
\end{abstract}

Kata Kunci: Kehidupan; Tindakan; Kemerdekaan; Hijrah; HOS Cokroaminoto

\section{Abstract}

This paper explores the understanding of the Basic Value of Peneleh and their suitability with the values believed by the authors and its relation to the author's expectations regarding the role of youth in civilization. The Jang Oetama Peneleh Foundation seeks to unite the views of all Peneleh Activists through the thought of HOS Cokroaminoto which is based on the Al-quran and al-Hadits. Insan Kamil is created, who realizes that he/she is an Abdillah or servant of Allah. The fight against the western paradigm that relies on the values of historical materialism is carried out by opposing the narrowness and shallowness of the Western mindset about humans and life. This fight triggers freedom and independence in thinking and action to become a driving force for the change (hijrah) of civilization.

Keywords : Life, Action, Independence, Hijrah, HOS Cokroaminoto 


\section{Oetoesan Hindia: Telaah Pemikiran Kebangsaan \\ Volume 2 No 2 Tahun 2020 Hlmn. 44-49}

Pertanyaan yang paling fundamental adalah mengapa Yayasan Peneleh Jang Oetama didirikan? Salah satunya adalah sebagai upaya dalam membangunkan kesadaran setiap insan yang hidup di atas Bumi ini untuk menyadari bahwa keberadaan dirinya bukanlah untuk dirinya sendiri, namun juga untuk umat manusia dan seluruh semesta. Hal tersebut erat kaitannya dengan tujuan Allah tuhan Yang Maha Esa menciptakan manusia diatas muka bumi ini yaitu sebagai Khalifah fil ardhi atau pemimpin di Bumi dan juga Abdillah atau hamba/pengabdi Allah. Maka dari itu bangunan kesadaran dan kemerdekaan dalam mengabdikan diri sebagai seorang pemimpin dalam berperan memandu kehidupan dan peradaban haruslah dilandasi oleh pengetahuan tentang siapa dirinya dan apa tujuan penciptaan atas dirinya sendiri juga akan ke mana dirinya setelah kehidupan ini berakhir yang selanjutnya diaksikan dalam kehidupan sehari-hari dengan mempertimbangkan aspek kemanusiaan dan kebermanfaatan terhadap kemaslahatan seluruh manusia yang ada di muka bumi.

Selanjutnya hal tersebut erat kaitannya dengan kerja sama antar manusia sehingga terbangun perasaan persaudaraan antara manusia sebagaimana telah disabdakan oleh Rasulullah bahwasanya antara umat muslim yang satu dengan yang lainnya adalah saudara. Kemudian apabila satu orang merasakan sakit maka yang lain juga akan merasakan sakitnya. Sehingga terbentuklah apa yang telah difirmankan oleh Allah dalam surah As-Saff ayat 4 yang berbunyi :

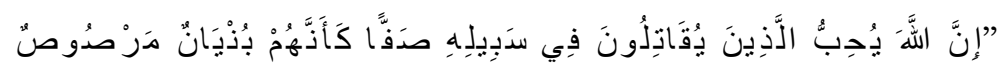

Sesungguhnya Allah menyukai orang yang berperang dijalan-Nya dalam barisan yang teratur seakan-akan mereka seperti suatu bangunan yang tersusun kokoh.”

Kalimat berperang dalam ayat tersebut tidak melulu dimaknai perang fisik ataupun pertumpahan darah. Pada masa sekarang ini hal tersebut dapat dimaknai secara lebih sempit yaitu berperang melawan diri sendiri atau bisa disebut berperang melawan hawa nafsu. Termasuk dalam makna tersebut adalah berperang melawan keangkuhan dan kesombongan manusia dalam membangun peradaban yang mengesampingkan nilai-nilai ke-esaan Tuhan dan bahkan cenderung menuhankan manusia atau dirinya sendiri karena kekerdilan ilmu pengetahuan yang dimilikinya. Kemenangan atas kesombongan manusia akan membentuk kekompakan dan persatuan antar umat yang memiliki kesadaran akan tingginya nilai-nilai ketauhidan yang harus diimplementasikan dalam bentuk peradaban yang meng-global yang kemudian membentuk peradaban madani yang religius dan berkebangsaan dengan parameter keberhasilan dilihat pada akhir tujuan itu dilihat pada kembalinya hamba kepada Allah tuhan Yang Maha Esa.

Dalam Nilai-nilai dasar kepenelehan (N2DkP) telah disebutkan bahwasanya pancasila merupakan salah satu rujukan sebagai bentuk penegasan bahwa Aktivis Peneleh meyakini keberadaan penjagaan Negara Kesatuan Republik Indonesia (NKRI). Hal tersebut berarti Aktivis Peneleh akan mengambil peran sebagai salah 


\section{Hijrah menuju peradaban... \\ Jamil, D.}

satu bagian untuk menjaga harkat dan martabat bangsa Indonesia yang pernah diberikan berbagai penilaian buruk di mata dunia seperti yang digambarkan oleh Belanda tahun 1915 di sebuah koran (Mulawarman, 2015):

"Orang Indonesia adalah segerombolan orang-orang pemalas, dungu, terbelakang, tidak mempunyai kemampuan berpikir, atau sekiranyapun ada sangat primitif. Menurut pendapat kami, orang Jawa adalah anak-anak nakal, banyak tingkah menyusahkan, malas. Bukanlah orang bawahan yang harus memberikan peringatan, tetapi sang tuan. Kitalah menjadi tuan”.

Peningkatan harkat dan martabat bangsa Indonesia di mata dunia tidaklah dapat terwujud jika kita masih menggunakan konsep untuk selalu mengikuti arus dari tatanan yang disusun oleh dunia. Kita sering menggunakan konsep Orientalisme atau menganggap pandangan orang barat lebih superior dari orang timur. Maka dari itu perlu kiranya kita sebagai bangsa Indonesia belajar dan menggali kembali sejarah yang dimiliki oleh bangsa Indonesia sebagai pemicu untuk meningkatkan kepercayaan diri terhadap tingginya nilai peradaban yang dimiliki oleh bangsa Indonesia yang salah satu cirinya adalah kaya akan bahasa, keanekaragaman kebudayaan yang dimiliki. Selain itu hal tersebut juga didukung oleh temuan manusia tertua yang ditemukan dari Jawa oleh Alfred Czarnetzki ("Manusia Jawa Purba Diduga Pernah Jelajahi Eropa," 2008), seorang profesor di Universitas Tuebingen berupa pecahan tulang tengkorak yang ditemukan disebuah tambang Jerman yang berasal dari manusia Jawa, yang mengartikan bahwa Indonesia adalah salah satu peradaban awal dunia.

Oleh sebab itu menciptakan suatu tatanan dunia baru yang sesuai dengan peradaban asli Nusantara dan nilai-nilai keislaman merupakan sebuah keniscayaan yang dapat terwujudkan. Selanjutnya dapat diketahui juga bahwasanya peradaban kapitalistik-sekularistik-liberalistik dalam tatanan peradaban global akan mengalami kehancuran melawan dirinya sendiri. Negara kapitalistik-sekularistik-liberalistik sedang melawan negara yang juga kapitalistik-sekularistik-liberalistik.

Terdapat manusia berkelompok yang memiliki niat dan keinginan untuk berubah, dan juga ingin menciptakan perubahan yang lebih dahsyat pada tatanan yang mengglobal seperti saat ini akan tetapi dengan keterlibatan Allah sebagaimana firman Allah dalam Al-Qur'an Surah Ar-Ra'ad ayat 11 yang berbunyi:

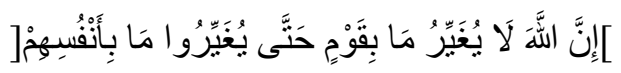

"Sesungguhnya Allah tidak akan mengubah keadaan suatu kaum, sebelum kaum itu sendiri mengubah apa yang ada pada diri mereka"

Pemaknaan dari ayat tersebut meletakkan sebegitu fundamentalnya peranan kesadaran masyarakat dalam melakukan perubahan sehingga nantinya Allah merestui untuk melakukan perubahan tersebut karena dipicu oleh masyarakat itu. Kesadaran tersebut dapat bermula dari muhasabah diri atau intropeksi terhadap 


\section{Oetoesan Hindia: Telaah Pemikiran Kebangsaan \\ Volume 2 No 2 Tahun 2020 Hlmn. 44-49}

kekurangnyamanan dalam tatanan peradaban yang ada ini. Barangkali kitalah yang sebenarnya tidak memiliki kesungguhan dalam memandu perjalanan dan gerak peradaban ini sebagai manusia yang memiliki tugas sebagai Khalifah fil ardhi, sehingga orang lain mengambil peran dan menggerakkan beradaban ini yang jauh dari nilai keimanan seperti bangunan peradaban kapitalistik-sekuleristik-liberalistik. Pada akhirnya tatanan tersebut "memperkosa" kita untuk menjadi bebek pengikut di dalam tatanan peradaban yang mereka ciptakan atau kita akhirnya menjadi "bebek peradaban”.

Hal tersebut berkaitan dengan masa sekarang ini yang mana kita ditodong dengan kebobrokan karakter yang dimiliki pemuda yang dikepung oleh ketidaktahuannya terhadap peran yang dimilikinya terhadap maju dan mundurnya sebuah bangsa dan peradaban. Padahal begitu pentingnya peran masyarakat yang didalamnya terdapat pemuda dalam pembangunan sebuah bangsa sehingga Bung Karno pernah mengatakan "Beri aku 1.000 orang tua, niscaya akan aku cabut semeru dari akarnya dan berikan aku 10 orang pemuda maka akan aku guncang dunia”.

Dari pernyataan tersebut dapatlah diketahui bahwasanya dalam perjalanan kehidupan manusia dari abad ke abad, generasi muda selalu memegang peranan yang cukup penting. Apabila rusak pemuda suatu negara maka rusaklah negara tersebut dan begitupula sebaliknya apabila bagus pemuda sebuah negara maka baguslah negara tersebut.

Dalam hal tersebut dengan jumlah penduduk global di wilayah ASEAN yang berusia di bawah 35 tahun mencapai presentase 60 persen. Dengan persentase yang besar ini, diperlukan penanaman nilai religius dan kebangsaan kepada kawula muda agar dapat kembali memperkuat peran melalui peningkatan kualitas dan kapasitas yang dimilikinya sehingga menjadi sosok yang berpengetahuan luas yang memiliki keterampilan dan berintegritas sebagai wujud pemuda yang berkarakter religius dan berkebangsaan dengan mengedepankan budi pekerti yang luhur.

Hal yang tidak boleh dikesampingkan bahwasanya akhlak di atas ilmu. Kebermanfaatan wawasan dan pengetahuan yang dimiliki seseorang bergantung pada bagaimana akhlak yang dibawanya. Sebagaimana dalam sebuah hadits yang diriwayatkan dari Abu Hurairah Radhiallahu 'Anhu, Rasulullah Shallallahu 'Alaihi Wasallam bersabda:

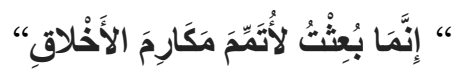

"Sesungguhnya aku diutus untuk menyempurnakan Akhlak". Begitu pentingnya akhlak pada perilaku manusia sehingga Allah mengutus nabi Muhammad langsung.

Wajiblah hukumnya seorang manusia, terlebih pemudanya mengutamakan akhlak dalam perilaku kesehariannya dalam berkehidupan. Itu juga merupakan bentuk implementasi dari tujuan awal penciptaan manusia yang perlu ditegaskan bahwasanya manusia adalah Abdillah atau hamba Allah di muka bumi ini yang tidak memiliki kepantasan sama sekali untuk bersifat congkak dan sombong juga 


\section{Hijrah menuju peradaban... \\ Jamil, D.}

membanggakan dirinya baik karena keilmuan yang dimiliki atau karena harta yang sedang dititipkan kepadanya. Akan tetapi perlu ditekankan kembali bahwasanya kita hanya diperlukan menghamba hanyalah kepada Allah Tuhan yang maha esa sehingga tidak lagi menghamba kepada selainnya baik itu berupa manusia lain, harta dan jabatan.

Jika pemuda sadar maka tidak akan terjadi apa yang disiratkan oleh H.O.S Cokroaminoto dalam Puisinya (Mulawarman, 2015):

"Bahasamu terpuji halus di seluruh dunia, dan sopan pula. Sebabnya kau menegur bangsa lain dengan bahasa kromo (hormat) dan orang lain menegurmu dengan bahasa ngoko (kasar).

Tidak jarang perilaku kesewenang-wenangan yang diberikan oleh bangsa lain kepada bangsa Indonesia justru diberikan penghormatan dengan porsi yang berlebihan. Itulah sebabnya menunduk bukan berarti dapat ditundukkan akan tetapi merupakan sebuah bentuk kita sebagai bangsa Indonesia menghormati bangsa lain karena sesama makhluk hidup di muka bumi ini dan kita juga menyadari bahwasnya sikap dan perilaku menghamba hanyalah sepatutnya diberikan kepada Allah Tuhan Yang Maha Esa. Itu juga merupakan bukti bahwasanya kita dapat menerima keberagaman yang ada akan tetapi tidak mentoleransi hal-hal yang menyimpang dari akhlak yang buruk sebagaimana perilaku imprealisme barat terhadap bangsa Indonesia dan membawa kebudayaan dan peradaban kapitalistik-sekularistik-liberalistik yang datang untuk menjajah dan memonopoli perdagangan hanyalah semata-mata demi keuntungan dirinya sendiri dengan mengembalikan kepada materi semata tanpa memperhatikan aspek bangunan kemanusiaan.

Dalam sejarah Indonesia para pemuda berjuang merebut kemerdekaan Indonesia dari tangan penjajah dengan berangkat dari kecemasan terhadap nasib sebuah bangsa. Ketika para kaum muda resah dengan perilaku penjajah yang telah menjarah tanah air kekayaan negerinya dan melakukan penindasan maka diraihlah kemerdekaan oleh bangsa Indonesia. Sayangnya, pada hari ini sedikit yang sadar bahwa sebenarnya bangsa Indonesia sedang dijajah secara mental dan pemikirannya yang berdampak pada akhlaknya.

Perlulah kiranya jika diri ini kembali mengambil peran sebagai Khalifah fil ardhi yang mampu melihat masa depan tidak sebagai diri sendiri bahkan tidak sebagai bangsa Indonesia akan tetapi diri ini dengan bantuan Allah haruslah mampu melihat ke depan sebagai umat manusia di seluruh dunia yang nasibnya terlunta-lunta karena kesalahan-kesalahannya sendiri. Pemuda seharusnya menjadi bagian dari penggerak hijrah peradaban melalui rekonsolidasi yang dilakukan oleh Yayasan Peneleh Jang Oetama yang mengumpulkan para insan yang memiliki kesadaran sebagai abdillah atau hamba allah. Diri perlu menyadari bahwasanya kesadaran pemuda haruslah dibangunkan kembali untuk tercapainya bangsa yang 100 persen merdeka dan berdaulat. Menggerakkan pemuda adalah suatu tantangan tersendiri (Kamayanti, 2019). Hal tersebut diperlukan penguatan Ketauhidan sebagai nilai religius yang imani. Maka sebenarnya diperlukan tiga perangkat dalam membangun sebuah 


\section{Oetoesan Hindia: Telaah Pemikiran Kebangsaan \\ Volume 2 No 2 Tahun 2020 Hlmn. 44-49}

peradaban yang religius dan berkebangsaan tersebut yaitu Kesadaran, Pengetahuan, dan Aksi. Dalam menjalankan tiga perangkat tersebut kita harus menyandarkan aksi pada resolusi pandang ketuhanan sehingga dengan sendirinya akan tercukupi segala yang menjadi kebutuhan dalam pembangunan peradaban bernilai religius dan berkebangsaan tersebut yang berakhir pada kembalinya hamba kepada Allah Tuhan Yang Maha Esa.

\section{Simpulan}

Dalam perlawanan melawan paradigma pemikiran barat yang bersandar pada nilai materi diperlukan bangunan kesadaran dalam diri. Kesadaran ini adalah dimilikinya amanah sebagai Khalifah fil ardhi yang dapat dimaknai sebagai pemandu jalannya peradaban tanpa mengesampingkan keberadaan bahwa diri adalah Abdillah atau hamba Allah yang sudah semestinya selalu menghamba padaNya. Penghambaan pada Allah diwujudkan dengan mengusahakan tercapainya sebesar-besar kepentingan umat manusia secara kolektif dengan tujuan akhir tetap kembali kepada Allah. Ketika kesadaran tersebut terbangun, diperlukan perenungan sebagai pengetahuan yang dapat dilakukan dalam bentuk intropeksi diri atau muhasabah apa yang mendasari terjadinya kekacauan tatanan peradaban tersebut karena sangat mungkin kesalahan tersebut berasal dalam diri kita sendiri sebagai hamba Allah yang seringkali melupakan Allah dalam setiap langkah dan gerak yang dilakukan.

Ketika bangunan pengetahuan tersebut telah dikokohkan langkah selanjutnya adalah melakukan rekonsolidasi kepada sesama hamba Allah yang juga memiliki kesadaran yang sama dengan tugasnya sebagai Khalifah fil ardhi yang juga menyadari bahwasanya nasib peradaban yang terlunta-lunta terjadi karena kesalahan-kesalahan dirinya sendiri yang kerapkali melupakan nilai-nilai ketauhidan dalam perilakunya. Sudah saatnya kita kembali memandu jalannya peradaban yang tertata pada nilai religius berkebangsaan. Jika kita mau melihat sejarah betapa luhurnya nilai peradaban yang dimiliki bangsa Indonesia, maka sudah semestinya kita menjadi penggerak utama hijrah peradaban tersebut dari karakter kapitalistik-sekularistikliberalistik menuju peradaban religiusitas berkebangsaan secara universal di seluruh dunia.

\section{Daftar Pustaka}

Kamayanti, A. (2019). Tantangan menggerakkan pemuda. Oetoesan-Hindia: Telaah Pemikiran Kebangsaan, 1(2), 59-68. https://doi.org/10.34199/oh.1.2.2019.002

Manusia Jawa Purba Diduga Pernah Jelajahi Eropa. (2008). Retrieved from https://nasional.kompas.com/read/2008/07/21/13170043/manusia.jawa.purba.didug a.pernah. $\% 0 \mathrm{~A} \% 0 \mathrm{~A} \% 0 \mathrm{~A}$

Mulawarman, A. D. (2015). Jang Oetama: Jejak dan Perjuangan HOS Tjokroaminoto. Yogyakarta: Galang Press. 